\title{
STRUCTURAL AND PHOTOLUMINESCENCE PROPERTIES OF ZnO NANOWIRES
}

\author{
G.YU. RUDKO, ${ }^{1}$ I.V. DUBROVIN, ${ }^{2}$ A.I. KLIMOVSKAYA, ${ }^{1}$ E.G. GULE, ${ }^{1}$ \\ P.M. LYTVYN, ${ }^{1}$ YU.M. LYTVYN, ${ }^{2}$ S.P. TURANSKA ${ }^{2}$ \\ ${ }^{1}$ V. Lashkaryov Institute of Semiconductor Physics, Nat. Acad. of Sci. of Ukraine \\ (41, Nauky Prosp., Kyiv 03028, Ukraine; e-mail: g_ rudko@ yahoo. com)
}

PACS 78.55.Et, 78.67.Uh

(C) 2012

${ }^{2}$ O. Chuiko Institute of Surface Chemistry, Nat. Acad. of Sci. of Ukraine

(17, Gen. Naumov Str., Kyiv 03164, Ukraine)

Arrays of $\mathrm{ZnO}$ nanowires are grown by the vapor-liquid-solid method on a silicon substrate. The results of XRD, SEM, and AFM studies show that the diameters of nanowires vary in the range (50-300) nm, and their length is up to $40 \mu \mathrm{m}$. The wires exhibit bright photoluminescence: the band corresponding to the near band edge region and one or two (depending on the growth conditions) defect-related bands. The intensity ratio of the bands reflects the non-stoichiometry of the material and can be controlled by the zinc evaporation temperature and the temperature in the growing zone.

\section{Introduction}

Semiconductor quasi-one-dimensional crystals nanowires (NWs) - are the promising crystalline materials with a unique set of properties. State-ofthe-art growth technologies provide an opportunity to synthesize NWs with the diameters from tens to hundreds of nanometers and with the lengths up to several thousand nanometers [1-4]. Due to their high mechanical strength, NWs can be used as building blocks in future generations of nano-electrical-mechanical devices [5]. Unique electrical and optical properties of NWs make them promising for the development of new electronic, optoelectronic, biomedical, sensor, and energy conversion nanodevices. In particular, $\mathrm{ZnO}$ nanowires have caused increasing interest due to the attractive optical properties of a parental bulk material. Bulk $\mathrm{ZnO}$ has wide direct band gap $(3.44 \mathrm{eV})$ and large exciton binding energy $\left(E_{B}^{3 D} \sim 0.06 \mathrm{eV}\right)$. Thus, $\mathrm{ZnO} \mathrm{NWs}$ are expected to find versatile applications in electronics devices that emit light in the UV spectral range.

$\mathrm{ZnO}$ NWs can be grown by various techniques such as physical evaporation [6-8], chemical vapor deposition [9-11], solvothermal method [12,13], etc. One of the most frequently used growth mechanisms is the vaporliquid-solid one $[2,14,15]$ (it is employed in the present study as well). The challenges of the existing synthesis techniques are the controllable growth of NWs arrays with well-determined diameters, lengths, shapes, surface density, homogeneity, etc. An important issue is the material of the substrate. At present, several groups [7, 16-18] have focused on the NWs growth on low-cost silicon substrates, which facilitate the design of semiconductor nanowire-based optoelectronic nanodevices.

In the present paper, we report on the fabrication of the arrays of randomly distributed $\mathrm{ZnO} \mathrm{NWs}$ on the polished single crystalline silicon substrates covered with golden nanoparticles. We analyze the correlation between the size, morphology, and photoluminescent properties of NWs and growth conditions. The origin of the differences in the photoluminescence spectra of NWs fabricated under different conditions is discussed.

\section{Experimental}

\subsection{Experimental set-up and materials}

A reactor for the synthesis of $\mathrm{ZnO}$ NWs arrays is shown in Fig. 1. The reactor was mounted inside a horizontal 


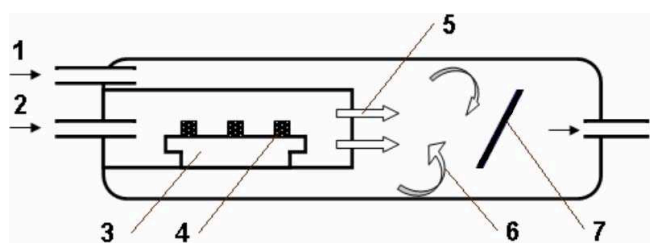

Fig. 1. Scheme of the reactor for the $\mathrm{ZnO}$ NWs synthesis: $1-$ oxygen flow, 2-argon flow, 3 - alundum boat, 4 - granules of metallic zinc, 5 - flow of the mixture of argon and zinc vapor, $6-$ flow of the mixture of argon, oxygen, and zinc vapor, $7-$ single crystalline silicon substrate with the nanogold covering

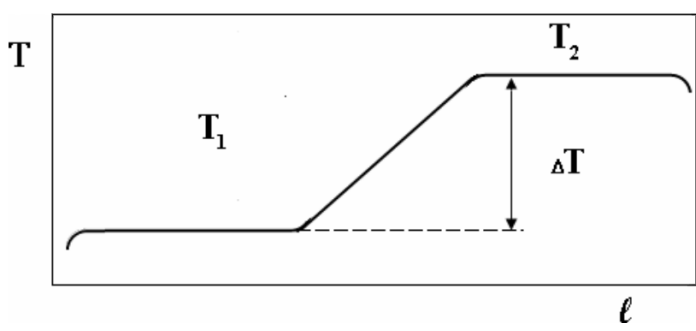

Fig. 2. Scheme of the temperature distribution within a tube-like furnace

tube furnace with two heating zones. The subdivision into two heating zones secured a required temperature gradient inside the reactor.

The source materials for growing the $\mathrm{ZnO} \mathrm{NWs}$ were the granules of metallic zinc (chemically pure) and oxygen and argon gases (of ultrapurity chemical quality). The gas flow inside the reactor was adjusted and controlled by the rotameters.

Polished single crystalline (111) silicon wafers were used as substrates.

To obtain the desirable density of randomly distributed crystallization centers on the silicon substrate surface, we used golden nanoparticles to initiate the growth. The colloidal golden nanoparticles were fabricated by the reduction of $\mathrm{AuCl}_{3}$ : the nanoparticlecontaining sol was synthesized by the addition of a $0.0075 \%$ solution of $\mathrm{H}\left[\mathrm{AuCl}_{4}\right]$ to a $0.005 \%$ solution of hydrazine hydrochloride. According to the AFM data, the sizes of particles in the thus obtained sol varied from 35 to $90 \mathrm{~nm}$.

To form a reliable coating of the substrate, the sedimentation of colloidal golden particles was carried out, by using carbon tetrachloride that provides a good wetting of the polished silicon surface. The surface density of catalyst nanoparticles was adjusted by variation of the colloidal solution concentration.

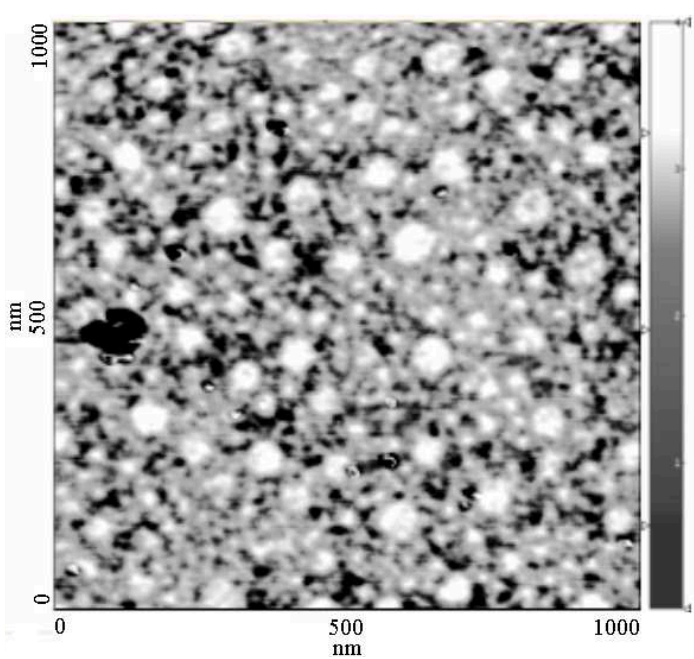

Fig. 3. Colloidal golden nanoparticles on the polished silicon substrate

\subsection{Characterization methods}

The morphologies and the sizes of as-grown $\mathrm{ZnO}$ NWs and the size of colloidal particles of a growth activator on the substrate were studied using a scanning electron microscope JSM-35 with an ICXA-733 X-ray microanalyzer (SEM) and an atomic-force microscope Digital Instruments NanoScope 300 (AFM). The crystal structures were confirmed by a DRON-3M X-ray diffractometer $\left(\mathrm{Cu}_{\alpha}, \lambda=0.15406 \mathrm{~nm}\right)$.

PL measurements were carried out at room temperature using a pulsed $\mathrm{N}_{2}$-laser $(337 \mathrm{~nm})$ as an excitation source. The excitation power density was $300 \mathrm{~W} / \mathrm{cm}^{2}$. The luminescence from the sample was dispersed by a MDR-23 spectrometer and detected with the use of a FEU-100 photomultiplier.

\section{Experimental Results and Discussion}

$\mathrm{ZnO} \mathrm{NWs}$ were synthesized in a gas flow using the reactor shown in Fig. 1. The temperature variation within a furnace is schematically shown in Fig. 2. A boat with zinc was placed in the cold zone.

The single crystalline silicon substrate was covered with colloidal golden nanoparticles by the sedimentation method described above. The typical structure of the gold-coated substrate is shown in Fig. 3.

Substrate (7) was mounted in the hot zone of the reactor across the argon flow from pipe (2). The argon flow transported zinc vapor toward the substrate. In the reactive volume in front of the silicon substrate, the vapor of $\mathrm{Zn}$ is oxidized by oxygen coming from pipe (1), and 

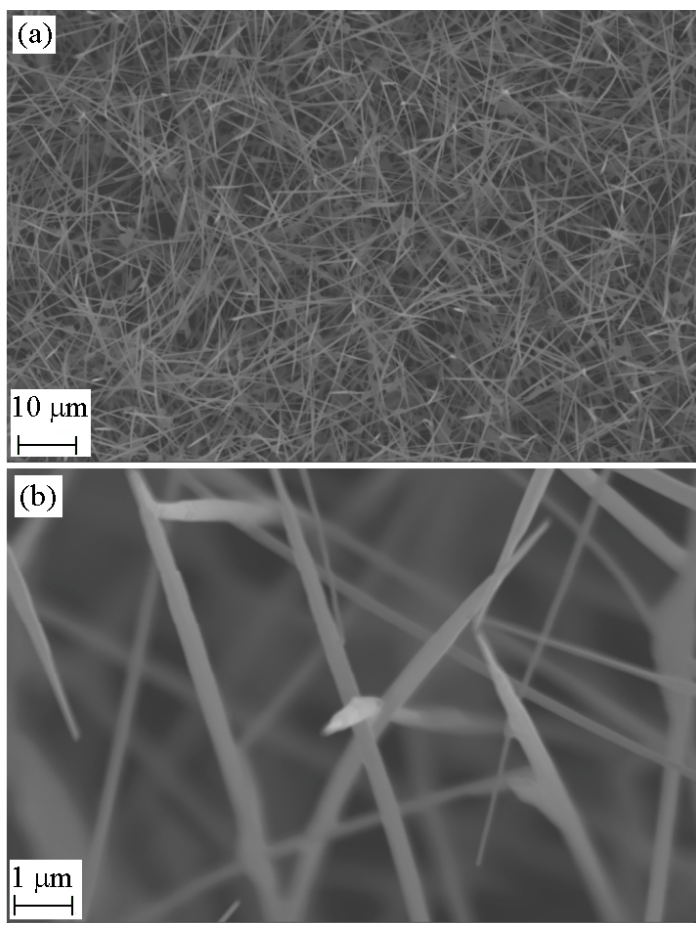

Fig. 4. SEM image of $\mathrm{ZnO}$ NWs grown on the polished silicon substrate seeded with colloidal golden nanoparticles

the arrays of $\mathrm{ZnO}$ NWs are formed on the gold-covered side of the silicon substrate. The flow rate of the $\mathrm{Zn}$ containing argon gas was $\sim 25 \mathrm{~cm}^{3} / \mathrm{s}$. It was higher than the oxygen flow rate by $\sim(10-20) \%$ in order to prevent the penetration of oxygen into that part of the reactor, where the granules of zinc were placed and, thus, to avoid the oxidation of zinc granules. By a variation of temperature regimes, the arrays of $\mathrm{ZnO} \mathrm{NWs}$ of various morphologies were obtained.

To optimize the synthesis, we studied the influence of the temperature regimes on the quality and the density of $\mathrm{ZnO}$ NWs. In the present study, the zinc evaporation temperature varied in the interval $T_{1}=700-850{ }^{\circ} \mathrm{C}$ (see Fig. 2), while the formation of the $\mathrm{ZnO}$ seeds and the growth of $\mathrm{ZnO}$ nanostructures occurred in the interval $\mathrm{T}_{2}=800-1050{ }^{\circ} \mathrm{C}$. The temperature gradient within the reaction zone was $\Delta T=100-200^{\circ} \mathrm{C}$.

We obtained the arrays of $\mathrm{ZnO}$ NWs that homogeneously covered silicon wafers. Figure $4, a$ shows a representative SEM image of a ZnO NWs array. As is seen from the Fig. 4, $a$, the nanowires have a typical diameter in the interval (50-300) $\mathrm{nm}$ and the length up to 40 $\mu \mathrm{m}$. Thus, the ratio between the length and the diameter can be as high as 3 orders of magnitude. The NWs are terminated by sharp tips (Fig. 4,b). This type of a NW shape is a prerequisite of efficient cold field emission

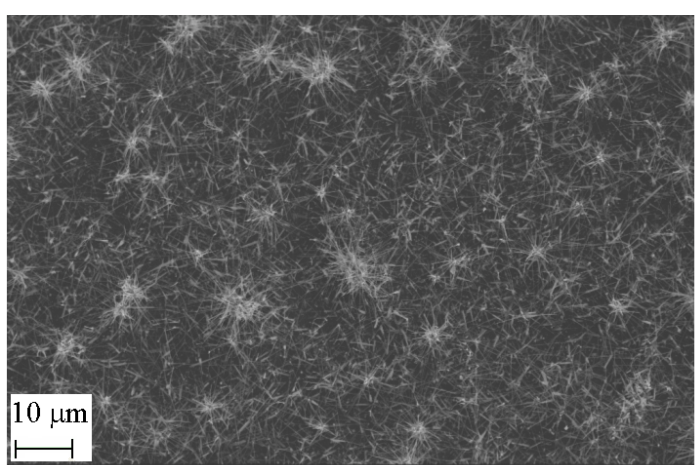

Fig. 5. SEM image of ZnO NWs grown on the polished silicon substrate

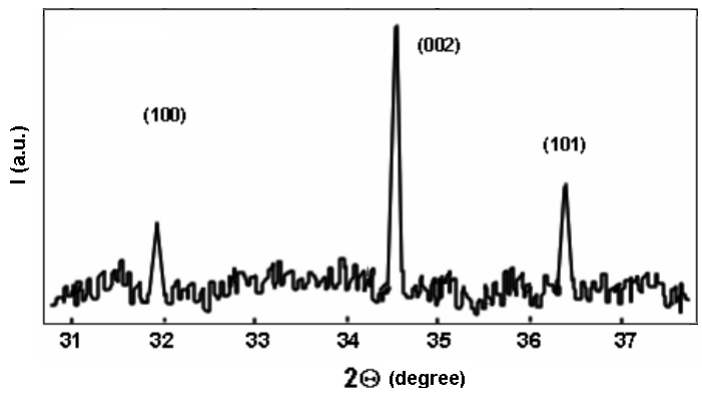

Fig. 6. Fragment of an XRD pattern of $\mathrm{ZnO}$ NWs

and is important for applications in the devices based on this effect. In fact, the quality of such devices, e.g., the potential that is applied to the electrodes, strongly depends on the material and the structure of a cathode, specifically, on its surface relief.

It should be noted that the structure and the homogeneity of the NWs arrays is predetermined by the conditions of growth initiation, i.e. on the very first stages of the growth of NWs. The micrograph in Fig. 4 shows an NWs array that was synthesized on the substrate covered with golden nanoparticles, which served to nucleate nanowires. It is seen that the NWs are homogeneously distributed on the substrate. In the case where the substrate surface was not pretreated with gold, the crystallization of $\mathrm{ZnO}$ took place at the surface defects of the substrate. In the latter case, the structure of an array is quite different: the NWs form bush-like clusters that are scattered on the substrate surface while the surface density of individual NWs in other parts of the substrate is rather low (Fig. 5).

The X-ray studies demonstrate that, in both growing modes, individual NWs have the hexagonal wurtzite structure. Figure 6 shows a typical X-ray diffraction pattern of $\mathrm{ZnO}$ NWs. All diffraction peaks correspond to the typical wurtzite structure of $\mathrm{ZnO}$. The elemental cell 


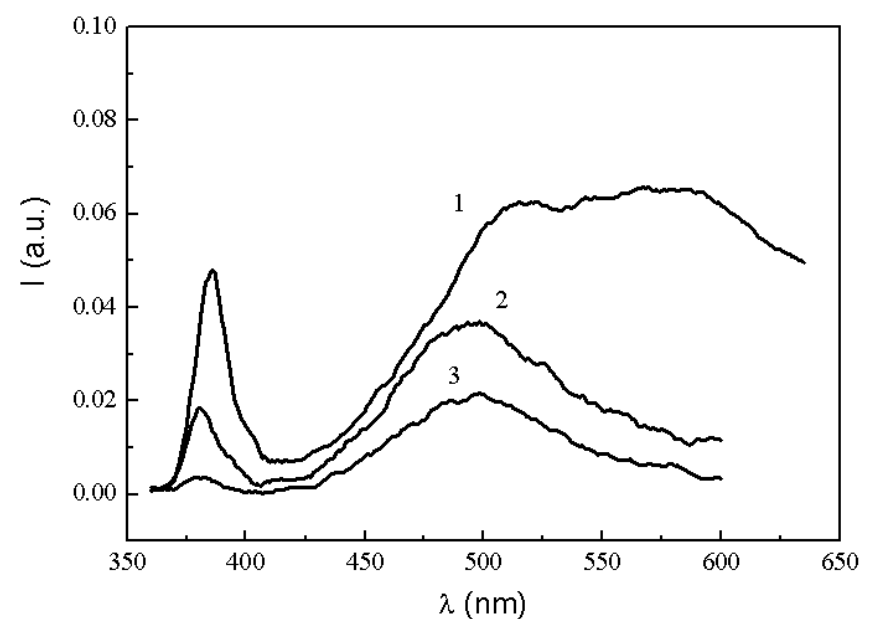

Fig. 7. PL spectra of NWs arrays grown at different temperatures of $\mathrm{Zn}$ evaporation: $1-700{ }^{\circ} \mathrm{C}, 2-750{ }^{\circ} \mathrm{C}, 3-830{ }^{\circ} \mathrm{C}$

parameters are $a=0.3240 \mathrm{~nm}$ and $c=0.5184 \mathrm{~nm} \mathrm{[19].}$ The NWs are grown along the 0001 crystalline axis.

We have analyzed the influence of the temperature regime of growth on the size and the photoluminescence characteristics of $\mathrm{ZnO}$ NWs. At lowest temperatures of the zinc evaporation (and, respectively, at lowest temperatures in the growth zone), the average diameter of NWs was comparatively high $(\sim 200-250 \mathrm{~nm})$. With increase in the evaporation temperature, the average diameter of NWs decreased to $\sim 100 \mathrm{~nm}$.

The spectra of the $\mathrm{ZnO}$ NWs photoluminescence are shown in Fig. 7. The studies of the photoluminescence revealed that all spectra exhibit UV emission (at $\sim 380$ $\mathrm{nm}$ ), which is related to the near-band edge transitions $[7,20]$. Another typical PL band, which is frequently observed in both bulk $\mathrm{ZnO}$ and $\mathrm{ZnO}$ NWs [2, 17, 2123], namely the green $\mathrm{PL}$ band (at $\sim 500 \mathrm{~nm}$ ), is also present in the spectra of all samples. It is a defect-related emission band commonly ascribed to oxygen vacancies $[2,17,21-23]$. One more band that is seen only in the samples grown at lowest temperatures (see curve 1 in Fig. 7) is not that common. It is the orange PL band; in the literature, it is ascribed to the oxygen-rich $\mathrm{ZnO}$ [24].

Both the UV and green bands are seen in the spectra of all samples synthesized at various temperatures. The ratio of the intensities of the UV and green PL peaks depends on the zinc evaporation temperature: an increase of the temperature favors the growth of the green PL intensity. This finding correlates with the conclusions made in $[2,17,21-23]$, where the green band was ascribed to oxygen vacancies. Thus, one can assume that the more intense zinc evaporation leads to the establishment of oxygen-deficient conditions of NWs growth. As a result, more oxygen vacancies are formed. Moreover, this assumption is also indirectly supported by the observation that the integrated PL intensity of the NWs diminishes with increase in the zinc evaporation temperature: a decrease of the integral intensity implies the higher rate of non-radiative transitions, thus pointing to the increased defectness of the crystals. At the lowest zinc evaporation temperature, the integrated PL intensity and the relative intensity of the near band edge emission are the highest. One more interesting feature is the presence of the orange band that is not observed in the spectra of the samples grown at higher temperatures. The intensity of the orange band is almost the same as that of the green band.

With regard for the attribution of this band to the defects related to oxygen-enriched zinc oxide [24], one can conclude that, in this case, the growth conditions favor the incorporation of oxygen into NWs. The difference between our results and the results of [24] is that both green and orange bands in our spectra are seen simultaneously, while the authors of [24] reported that they observed only the alternative presence of these bands in the spectra. Taking both results into account, it can be assumed that the arrays of NWs obtained at the lower zinc evaporation temperatures contain both oxygen-deficient and oxygen enriched NWs. In the arrays obtained at higher temperatures of the zinc evaporation, only oxygen-deficient NWs are present.

\section{Conclusions}

Statistically distributed arrays of ZnO NWs are grown on chemically polished silicon substrates pre-treated by colloidal gold to serve the centers of crystallization. The arrays contain NWs of a high crystalline quality that are grown along the $\langle 001\rangle$ crystalline axis.

The influence of the growth conditions on the properties of NWs is studied. The results of morphological and photoluminescent studies show that an increase of the zinc evaporation temperature and the temperature in the growing zone favors the growth of the arrays consisting of NWs of smaller average diameters, as well as oxygen-deficient growth conditions.

1. Y.S. Chang and J.M. Ting, Thin. Solid. Films 398-399, 29 (2001).

2. M.H. Huang, Y. Wu, H. Feick et al., Adv. Mater. 13, 113 (2001).

3. X.M. Sun, X. Chen, Z.X. Deng et al., Mater. Chem. Phys. 78, 99 (2002). 
4. Y.W. Heo, D.P. Norton, L.C. Tien et al., Mater. Sci. Eng. R 47, 1 (2004).

5. X. Wang, J. Song, J. Liu et al., Science 316, 102 (2007).

6. S.C. Lyu, Y. Zhang and C.J. Lee, Chem. Mater. 15, 3294 (2003).

7. A. Umar, S.H. Kim, J.H. Kim et al., Mater. Lett. 61, 4954 (2007).

8. H.C. Hsu and W.F. Hsieh, Sol. St. Commun. 131, 371 (2004)

9. C.Y. Wu, H.C. Hsu, H.M. Cheng et al., J. Cryst. Growth 287, 189 (2006).

10. L.N. Protasova, E.V. Rebrov, K.L. Choy et al., Catal. Sci. Technol. 1, 768 ( 2011).

11. J.B. Baxter and E.S. Aydil, J. Electrochem. Soc. 156, H52 (2009).

12. A. Dev, S. Kar, and S. Chaudhuri, J. of Nanosci. and Nanotechn. 7, 2778 (2007).

13. B. Wen, Y. Huang, and J.J. Boland, J. Phys. Chem. C 112, 106 (2008).

14. E. Comini, C. Baratto, G. Faglia et al., Progr. Mater. Sci. 54, 1 (2009).

15. J. Zhang, Y. Yang, F. Jiang et al., Solid State Chem. 178, 2804 (2005).

16. Y. Zhang, H. Jia, R. Wang et al., Appl. Phys. Lett. 83, 4631(2003).

17. W. Sang, Y. Fang, J. Fan et al., J. Cryst. Growth 299, $272(2007)$.

18. L. Yang, J. Yang, D. Wang et al., Physica E 40, 920 (2008)
19. International Tables of X-Ray Crystallography (Kynoch Press, Birmingham, 1974).

20. Y. Zhang, B. Lin, Z. Fu et al., Opt. Mater. 28, 1192 (2006).

21. K. Vanheusden, W.L. Warren, C.H. Seager et al., J. Appl. Phys. 79, 7983 (1996).

22. K. Vanheusden, C.H. Seager, W.L. Warren et al., Appl. Phys. Lett. 68, 403 (1996).

23. S.C. Lyu, Y. Zhang, H. Ruh et al., Chem. Phys. Lett. 363, 134 (2002).

24. S.A. Studenikin, N. Golego, and M. Cociverab, J. Appl. Phys. 84, 2287 (1998).

Received 18.01.12

\section{СТРУКТУРНІ ТА ФОТОЛЮМІНЕСЦЕНТНІ}

ВЛАСТИВОСТІ НАНОНИТОК ZnO

Г.Ю. Рудъко, І.В. Дубровін, А.І. Клімовсъка, Є.Г. Гуле, П.М. Литвин, Ю.М. Литвин, С.П. Турансъка

$\mathrm{P}$ е $з$ ю м е

Масиви нанодротів $\mathrm{ZnO}$ було вирощено за механізмом парарідина-кристал на кремнієвих підкладках та було досліджено методами рентгенівської дифрактометрії, скануючої електронної мікроскопії та атомно-силової мікроскопії. Результати цих досліджень свідчать про те, що діаметри нанодротів варіюються в межах 50-300 нм, а їх довжина сягає 40 мкм. Для вирощених нанодротів характерна інтенсивна фотолюмінесценція, в спектрі якої домінують близько-крайова смуга та одна чи дві (залежно від умов вирощування) дефектні смуги. Співвідношення інтенсивностей цих смуг відображає нестехіометричність матеріалу і залежить від температури випаровування цинку та температури в зоні росту нанодротів. 